R.K. Srivastava MD, K.K. Gombar MD,* A.H. Kaur MD, P. Khosla MD

\title{
Attenuation of morphine-induced antinociception by L-glutamic acid at the spinal site in rats
}

The present experimental study was planned to evaluate the effect of intrathecal administration of L-glutamic acid upon antinociception produced by intrathecal morphine in a prospective-controlled manner in conscious freely mobile Sprague-Dawley albino rats. After chronic catheterization of the spinal subarachnoid space, rats were randomly allocated into 12 treatment groups of ten each and the same number of rats served as saline control for the comparison. L-glutamic acid (100 mmol), morphine $(1.2 \mathrm{mmol})$, ketamine $(50 \mathrm{mmol})$ and saline $(150 \mathrm{mmol})$ were injected intrathecally in $5 \mu \mathrm{l}$ volumes. Naloxone was injected in a dose of $1 \mathrm{mg} \cdot \mathrm{kg}^{-1} \mathrm{im}$. Immediately before and 15,30 min, 1,2 and $3 \mathrm{hr}$ afier injection, rats were subjected to a thermal noxious stimulus, using a tailflick technoanalgesiometer and tail-fick latencies (TFL) were recorded. Intrathecal administration of L-glutamic acid attenuated the antinociceptive effect of intrathecal morphine with a decrease in TFL (1.4 $\pm 0.3 \mathrm{sec} ; P<0.0001)$ from $6.6 \pm$ $0.3 \mathrm{sec}$. Ketamine led to abolition of this effect $(P<0.01)$. In rats, pretreated with naloxone, there was restoration as well as augmentation of morphine-induced antinociception in the presence of L-glutamic acid with an increase in TFL $9.0 \pm$ $0.4 \mathrm{sec} ; P<0.0001$ ). We conclude that there is modulation of opioid receptors by $L$-glutamic acid at the spinal site in rats.

\section{Key words}

ANTAGONISTS, MISCELLANEOUS: NMDA-receptor,

ketamine;

ANTAGONISTS, OPIOID: naloxone;

ANALGESICS: morphine;

NEUROREGULATORS: excitatory neurotransmitters; PAIN: antinociception;

RECEPTOR: NMDA, antagonist ketamine.

From the Department of Pharmacology and *Department of Anaesthesiology, Pt. B.D.S. Medical College and Hospital, Rohtak-124001, India.

Address correspondence to: Dr. R.K. Srivastava, 27/9J, Medical Enclave, Pt. B.D.S. Medical College \& Hospital, ROHTAK-124001, India.

Accepted for publication 27th January, 1995.
Ce travail expérimental prospectif et contrôlé vise à évaluer l'influence de l'administration intrathécale d'acide L-glutamique sur l'antinociception produite par la morphine intrathécale sur des rats albinos mobiles de race Sprague-Dawley. Après la cathétérisation à demeure de l'espace sous-arachnoïdien, les rats sont répartis de façon randomisée entre 12 groupes de traitement de dix chacun et un même nombre de rats traités au soluté physiologique servent de contrôles comparatifs. L'acide Lglutamique (100 mmol), la morphine $(1,2 \mathrm{mmol})$, la kétamine (50 mmol) et le physiologique (150 $\mathrm{mmol}$ ) sont injecté par voie intrathécale en volumes de $5 \mu \mathrm{l}$. La naloxone est injectée à la dose de $1 \mathrm{mg} \cdot \mathrm{kg}^{-1} \mathrm{im}$. Immédiatement avant et 15,30 min, 1,2 et $3 \mathrm{~h}$ après línjection, les rats sont soumis à un stimulus nociceptif thermique avec mesure au technoanalgésiomètre des oscillations de la queue du rat (tail flicker); les latences de celles-ci (TFL) sont enregistrées. L'administration intrathécale d'acide L-glutamique atténue l'effet antinociceptif de la morphine intrathécale avec une diminution du TFL $(1,4$ $\pm 0,3 \mathrm{sec} ; P<0,0001)$ pour une valeur initiale de $6,6 \pm 0,3$ sec. La kétamine abolit cet effet $(P<0,01)$. Chez les rats prétraités à la naloxone, on remarque la restauration et l'exagération de l'antinociception induite par la morphine avec une augmentation du TFL $(9,0 \pm 0,4 \mathrm{sec} ; P<0,0001)$. Nous concluons que modulation des récepteurs opiacés par l'acide L-glutamique chez le rat se situe au niveau de la moelle épinière.

L-glutamic acid, a precursor of GABA is an excitatory amino acid (EAA) present in the brain. In addition to its anabclic and catabolic effects it serves as the main mediator of fast excitatory neurotransmission in the mammalian spinal cord' and vertebrate neurons. ${ }^{2}$ At least three EAA receptor subtypes coexist including those activated by the agonists-N-methyl-D-aspartate (NMDA) (RS)- $\alpha$-amino-3-hydroxy-5-methyl-4-isoxazole-propionic acid HBR (AMPA) and kainate. ${ }^{1,3}$ Glutamate, an NMDA-receptor agonist ${ }^{4}$ has been implicated in hypoxic ischaemic brain damage which can be attenuated by morphinan derivatives ${ }^{5}$ and naloxone. ${ }^{6}$ 
There is much to suppor! the involvement of NMDAreceptor, glutamate and aspartate in nociceptive processing in the spinal cord ${ }^{7-13}$ and antagonists to the NMDAreceptor have been shown to inhibit the response to noxious stimuli in dorsal horn neurons of spinal cord $8,10,11$ and produce analgesia. ${ }^{9,14,15}$ The NMDA receptor blockers such as dissociative anaesthetics phencyclidine (PCP) and ketamine block NMDA-elicited responses due to noxious stimuli in the spinal cord. ${ }^{16,17}$ Selective NMDA-receptor antagonists 3-(2-carboxy piperazin-4-yl) propyl-1-phosphonic acid (CPP) ${ }^{15,16}$ and MK-801 19,20 have been shown to produce antinociception and block hyperalgesia after intrathecal (it) administration.

However, in some studies ${ }^{21-23}$ glutamate and NMDA produce antinociception when administered to the same periaqueduct grey region (PAG) sites where morphine acts. The opioid antagonist, naloxone, blocks neither glutamate nor NMDA antinociception. ${ }^{21,23}$

The present investigation was undertaken to determine the influence of L-glutamic acid on morphine-induced antinociception at the spinal site in rats.

\section{Methods}

After approval of the protocol by the Hospital Ethics Committee, the study was carried out in freely mobile and conscious Sprague-Dawley albino rats weighing $250-300 \mathrm{~g}$ of either sex. The animals were anaesthetised with nembutal $30 \mathrm{mg} \cdot \mathrm{kg}^{-1}$ ip and chronic catheterization of the spinal subarachnoid space was done with a PE-10 catheter by inserting it through the atlanto-occiptal membrane and advancing $8.5 \mathrm{~cm}$ in a caudal direction following the method described by Yaksh and Rudy. ${ }^{24}$ Catheterized rats were individually housed under a nor$\mathrm{mal}$ 12:12 hr light/dark cycle. Water and food were available ad libidum. The experiments were conducted after ten days of catheterization.

L-glutamic acid $100 \mathrm{mmol}$ (Sigma) was dissolved in phosphate buffer $0.2 \mathrm{~mol}(\mathrm{pH} 6.5)$ and the $\mathrm{pH}$ was adjusted to 6.5 with $12 \mathrm{~mol} \mathrm{NaOH}$. Ketamine hydrochloride $50 \mathrm{mmol}$ (Themis Chem Ltd. Bombay, India) was dissolved in $150 \mathrm{mmol} \mathrm{NaCl}$. Morphine sulphate $1.20 \mathrm{mmol}$ (Pharma Chemical Lab Solan, India) and naloxone hydrochloride (EI Dupont Wilmington) were dissolved in distilled water. Rats were treated with naloxone 1 $\mathrm{mg} \cdot \mathrm{kg}^{-1} \mathrm{im}$. Drugs were injected intrathecally in $5 \mu \mathrm{l}$ volumes using a microlitre syringe via a chronically inserted catheter followed by $5 \mu$ l vehicle to flush the catheter.

Rats were randomly allocated to 12 treatment groups of ten each and same number of rats served as controls that received saline $(150 \mathrm{mmol} i t$ or $i m)$ for the comparison. Rats were injected either with one of L-glutamic acid $(100 \mathrm{mmol} i t)$, morphine $(1.20 \mathrm{mmol} i t)$, ketamine
(50 mmol it), naloxone $\left(1 \mathrm{mg} \cdot \mathrm{kg}^{-1} \mathrm{im}\right)$ or with their different combinations (Table I).

Nociception was assessed using a tail-flick technoanalgesiometer (Techno-Electronics, Lucknow, India) as described by Davies et al. ${ }^{25}$ The rat's tail $2 \mathrm{~cm}$ from the tip was placed into a groove that housed a nichrome thermal wire that was heated to give a baseline TFL ranged from $1.5-2.5 \mathrm{sec}$. The heat was automatically terminated at ten seconds to prevent tissue damage. The TFL was recorded after a time interval of $15,30 \mathrm{~min}$, 1,2 and $3 \mathrm{hr}$ from the last injection.

Statistical analysis of the data was performed using one-way ANOVA and the Newman-Keuls test was applied for post-hoc comparison of group means. Differences were considered significant at $P<0.01$.

\section{Results}

There were no differences in the baseline TFL values of rats among groups $\left(F_{11,108}=1.4 ; N S\right)$. Intrathecal morphine $(1.20 \mathrm{mmol})$ produced an increase in TFL $(6.8 \pm$ $0.2 \mathrm{sec} ; P<0.001)$ in comparison with saline $(2.1 \pm$ $0.1 \mathrm{sec}$ ) (Table II). No differences were observed with L-glutamic acid $(100 \mathrm{mmol} i t)$ or naloxone $\left(1 \mathrm{mg} \cdot \mathrm{kg}^{-1}\right.$ im) on TFL $\left(\mathrm{F}_{1,18}=6.20\right.$, NS; $\mathrm{F}_{1,18}=2.16$, NS respectively). However, with ketamine $(50 \mathrm{mmol} i t)$ there was an increase in TFL $\left(\mathrm{F}_{1,18}=57.6 ; P<0.01\right)$.

A combination of L-glutamic acid $(100 \mathrm{mmol} i t)$ and morphine $(1.20 \mathrm{mmol} i t)$ decreased TFL $(1.4 \pm 0.3 \mathrm{sec}$; $P<0.0001)$. In some rats, receiving L-glutamic acid and morphine, the response to pain became so intense that vocalization was noted on exposure to thermal noxious stimulus (Table II).

The increase in TFL ( $7.4 \pm 0.6 \mathrm{sec} ; P<0.001)$ after ketamine $(50 \mathrm{mmol} i t)$ and morphine $(1.20 \mathrm{mmol} i t)$ was not different from TFL obtained with intrathecal saline and morphine (Table II).

Rats treated with naloxone $\left(1 \mathrm{mg} \cdot \mathrm{kg}^{-1} \mathrm{im}\right)$ and morphine $(1.20 \mathrm{mmol} i t)$ did not show any change in TFL $(2.2 \pm 0.2 \mathrm{sec})$. Combination of ketamine $(50 \mathrm{mmol} i t)$ and L-glutamic acid $(100 \mathrm{mmol} i t)$ too had no effect. Also, there was no effect of naloxone and L-glutamic acid on TFL (Table III).

The effect produced on TFL with naloxone (1 $\left.\mathrm{mg} \cdot \mathrm{kg}^{-1} i \mathrm{~m}\right)$ and ketamine ( $\left.50 \mathrm{mmol} i t\right)$ was no different from that produced with ketamine alone $\left(\mathrm{F}_{1,18}=5.52\right.$; NS). Rats receiving a combination of ketamine $(50 \mathrm{mmol}$ it), L-glutamic acid (100 mmol $i t)$ and morphine (1.20 mmol it) showed an increase in TFL $(7.6 \pm 0.2 \mathrm{sec} ; P$ $<0.001$ ), compared with baseline but this increase was no different from that produced by ketamine, saline and morphine $\left(\mathrm{F}_{1,18}=2.90 ; \mathrm{NS}\right)$. However, compared with morphine or ketamine alone this increased TFL was different $(P<0.001)$ (Tables II, III). 
TABLE I Schedule for intrathecal injections of morphine ( $1.20 \mathrm{mmol})$, L-glutamic acid (100 mmol), ketamine $(50 \mathrm{mmol})$ and saline $(150 \mathrm{mmol})$ at different time intervals in various groups. Naloxone was given, $1 \mathrm{mg} \cdot \mathrm{kg}^{-1}$, im

\begin{tabular}{|c|c|c|c|c|}
\hline \multirow{2}{*}{$\begin{array}{l}\text { Group } \\
(n=10)\end{array}$} & \multicolumn{4}{|c|}{ Time of injection (min) } \\
\hline & 0 & 5 & 10 & 15 \\
\hline \multirow{2}{*}{$\begin{array}{ll}1 & \text { (i) } \\
& \text { (ii) }\end{array}$} & Morphine & - & - & - \\
\hline & Saline & - & - & - \\
\hline \multirow{2}{*}{$\begin{array}{ll}2 & \text { (i) } \\
& \text { (ii) }\end{array}$} & L-glutamic acid & - & - & - \\
\hline & Saline & - & - & - \\
\hline \multirow{2}{*}{$\begin{array}{ll}3 & \text { (i) } \\
& \text { (ii) }\end{array}$} & Ketamine & - & - & - \\
\hline & Saline & - & - & - \\
\hline \multirow{2}{*}{$\begin{array}{ll}4 & \text { (i) } \\
& \text { (ii) }\end{array}$} & Naloxone & - & - & - \\
\hline & Saline & - & - & - \\
\hline \multirow[t]{2}{*}{5} & L-glutamic acid & - & Morphine & - \\
\hline & Saline & - & Morphine & - \\
\hline \multirow{2}{*}{$\begin{array}{ll}6 & \text { (i) } \\
& \text { (ii) }\end{array}$} & Ketamine & - & - & Morphine \\
\hline & Saline & - & - & Morphine \\
\hline \multirow{2}{*}{$\begin{array}{ll}7 & \text { (i) } \\
& \text { (ii) }\end{array}$} & Naloxone & - & - & Morphine \\
\hline & Saline (im) & - & - & Morphine \\
\hline \multirow{2}{*}{$\begin{array}{ll}8 & \text { (i) } \\
& \text { (ii) }\end{array}$} & Ketamine & L-glutamic acid & - & - \\
\hline & Saline & L-glutamic acid & - & - \\
\hline \multirow{2}{*}{$\begin{array}{ll}9 & \text { (i) } \\
& \text { (ii) }\end{array}$} & Naloxone & L-glutamic acid & - & - \\
\hline & Saline (im) & L-glutamic acid & - & - \\
\hline \multirow{2}{*}{$\begin{array}{ll}10 & \text { (i) } \\
& \text { (ii) }\end{array}$} & Naloxone & - & Ketamine & - \\
\hline & Saline (im) & - & Ketamine & - \\
\hline \multirow{2}{*}{$\begin{array}{ll}11 & \text { (i) } \\
& \text { (ii) }\end{array}$} & Ketamine & L-glutamic acid & - & Morphine \\
\hline & Saline & L-glutamic acid & - & Morphine \\
\hline \multirow{2}{*}{$\begin{array}{ll}12 & \text { (i) } \\
& \text { (ii) }\end{array}$} & Naloxone & L-glutamic acid & - & Morphine \\
\hline & Saline (im) & L-glutamic acid & - & Morphine \\
\hline
\end{tabular}

TABLE II Effects of morphine $(1.20 \mathrm{mmol} i t)$, L-glutamic acid (100 mmol $i t)$, ketamine $(50 \mathrm{mmol} i t)$, saline (150 mmol it or $i m$ ) and naloxone $\left(1 \mathrm{mg} \cdot \mathrm{kg}^{-1} \mathrm{im}\right.$ ) alone and their different combinations on tail flick latency (TFL)

\begin{tabular}{|c|c|c|c|c|}
\hline \multirow[b]{2}{*}{$\begin{array}{l}\text { Groups } \\
(n=10)\end{array}$} & \multirow[b]{2}{*}{ Drugs } & \multicolumn{2}{|l|}{$T F L \mathrm{sec}$} & \multirow[b]{2}{*}{ Pvalue } \\
\hline & & $\begin{array}{l}\text { Baseline } \\
\text { (mean } \pm S E M)\end{array}$ & $\begin{array}{l}\text { Afier I hour } \\
\text { (mean } \pm \text { SEM) }\end{array}$ & \\
\hline \multirow{2}{*}{$\begin{array}{ll}1 & \text { (i) } \\
& \text { (ii) }\end{array}$} & Morphine & $2.0 \pm 0.2$ & $6.8 \pm 0.2$ & \multirow[t]{2}{*}{$<0.001$} \\
\hline & Saline & $1.8 \pm 0.3$ & $2.1 \pm 0.1$ & \\
\hline \multirow{2}{*}{$\begin{array}{ll}2 & \text { (i) } \\
& \text { (ii) }\end{array}$} & L-glutamic acid & $2.1 \pm 0.2$ & $2.4 \pm 0.3$ & \multirow[t]{2}{*}{$>0.01$} \\
\hline & Saline & $2.3 \pm 0.1$ & $2.2 \pm 0.2$ & \\
\hline \multirow{2}{*}{$\begin{array}{ll}3 & \text { (i) } \\
& \text { (ii) }\end{array}$} & Ketamine & $2.0 \pm 0.1$ & $3.3 \pm 0.3$ & \multirow[t]{2}{*}{$<0.01$} \\
\hline & Saline & $2.1 \pm 0.3$ & $2.6 \pm 0.3$ & \\
\hline \multirow{2}{*}{$\begin{array}{ll}4 & \text { (i) } \\
& \text { (ii) }\end{array}$} & Naloxone & $1.9 \pm 0.1$ & $2.0 \pm 0.1$ & \multirow[t]{2}{*}{$>0.01$} \\
\hline & Saline (im)' & $1.8 \pm 0.3$ & $2.1 \pm 0.3$ & \\
\hline \multirow{2}{*}{$\begin{array}{ll}5 & \text { (i) } \\
& \text { (ii) }\end{array}$} & L-glutamic acid + morphine & $2.1 \pm 0.2$ & $1.4 \pm 0.3$ & \multirow[t]{2}{*}{$<0.0001$} \\
\hline & Saline + morphine & $2.3 \pm 0.2$ & $6.6 \pm 0.3$ & \\
\hline \multirow{2}{*}{$\begin{array}{ll}6 & \text { (i) } \\
& \text { (ii) }\end{array}$} & Ketamine + morphine & $2.1 \pm 0.2$ & $7.4 \pm 0.6$ & \multirow[t]{2}{*}{$>0.01$} \\
\hline & Saline + morphine & $2.2 \pm 0.4$ & $6.8 \pm 0.3$ & \\
\hline \multirow{2}{*}{$\begin{array}{ll}7 & \text { (i) } \\
& \text { (ii) }\end{array}$} & Naloxone + morphine & $2.3 \pm 0.2$ & $2.2 \pm 0.2$ & \multirow[t]{2}{*}{$<0.001$} \\
\hline & Saline $(i m)+$ morphine & $2.0 \pm 0.1$ & $6.8 \pm 0.3$ & \\
\hline
\end{tabular}

$P$ values compared to values from saline-treated rats.

Rats treated with naloxone $\left(1 \mathrm{mg} \cdot \mathrm{kg}^{-1} \mathrm{im}\right)$, Lglutamic acid (100 mmol it) and morphine (1.20 mmol it) produced considerable increase in TFL $(9.0 \pm 0.4 \mathrm{sec}$;
$P<0.0001)$ compared with that produced by the combination of saline $(150 \mathrm{mmol} \mathrm{im})$, L-glutamic acid (100 $\mathrm{mmol} i t)$, and morphine $(1.20 \mathrm{mmol} i t)$ or by the com- 
TABLE III Effects of different drug combinations on tail flick latency (TFL); ketamine ( $50 \mathrm{mmol} i t)$, Lglutamic acid (100 mmol it), morphine $(1.20 \mathrm{mmol} i t)$, saline $(150 \mathrm{mmol} i t$ or $i m)$ and naloxone $\left(1 \mathrm{mg} \cdot \mathrm{kg}^{-1} \mathrm{im}\right)$

\begin{tabular}{|c|c|c|c|c|}
\hline \multirow[b]{2}{*}{$\begin{array}{l}\text { Groups } \\
(n=10)\end{array}$} & \multirow[b]{2}{*}{ Drugs } & \multicolumn{2}{|l|}{$T F L \sec$} & \multirow[b]{2}{*}{$P$ value } \\
\hline & & $\begin{array}{l}\text { Baseline } \\
\text { (mean } \pm S E M)\end{array}$ & $\begin{array}{l}\text { After I hour } \\
\text { (mean } \pm \text { SEM) }\end{array}$ & \\
\hline \multirow{2}{*}{8} & Ketamine + L-glutamic acid & $2.0 \pm 0.2$ & $3.1 \pm 0.3$ & $>0.01$ \\
\hline & Saline + L-glutamic acid & $2.2 \pm 0.2$ & $2.5 \pm 0.1$ & \\
\hline \multirow{2}{*}{9} & Naloxone + L-glutamic acid & $2.1 \pm 0.3$ & $2.3 \pm 0.3$ & $>0.01$ \\
\hline & Saline + L-glutamic acid & $2.3 \pm 0.4$ & $2.6 \pm 0.3$ & \\
\hline \multirow{2}{*}{10} & Naloxone + ketamine & $2.3 \pm 0.1$ & $3.7 \pm 0.4$ & $>0.01$ \\
\hline & Saline $(i m)+$ ketamine & $2.0 \pm 0.3$ & $3.5 \pm 0.2$ & \\
\hline \multirow{2}{*}{$\begin{array}{ll}11 & \text { (i) } \\
& \text { (ii) }\end{array}$} & Ketamine + L-glutamic acid + morphine & $2.4 \pm 0.4$ & $7.6 \pm 0.2$ & $>0.01$ \\
\hline & Ketamine + saline + morphine & $1.8 \pm 0.1$ & $7.0 \pm 0.2$ & \\
\hline 12 (i) & Naloxone + L-glutamic acid + morphine & $2.3 \pm 0.3$ & $9.0 \pm 0.4$ & $<0.0001$ \\
\hline (ii) & Saline $(i m)+$ L-glutamic acid + morphine & $2.0 \pm 0.3$ & $2.1 \pm 0.4$ & \\
\hline
\end{tabular}

$P$ values compared with saline-treated rats.

bination of ketamine (50 mmol $i t)$, L-glutamic acid (100 $\mathrm{mmol} i t)$ and morphine (1.20 mmol $i t)$ (Table III).

\section{Discussion}

Morphine, a potent analgesic, produces dose-dependent antinociception when injected intrathecally in rats. In our pilot work, we found that the $\mathrm{ED}_{50}$ of morphine sulphate for antinociception is $1.20 \mathrm{mmol}$. Prior administration of naloxone antagonises morphine-induced antinociception which can be attributed to its opioid antagonist property.

L-glutamic acid, an excitatory neurotransmitter and NMDA receptor agonist, does not affect the pain threshold but stimulates behaviour in rats. L-glutamate has been reported to be a nociceptive neurotransmitter in the spinal cord. ${ }^{7-13}$ However, in some studies, ${ }^{21,23}$ microinjection of glutamate has been found to produce antinociception.

In the present study, L-glutamic acid in dose of 100 $\mathrm{mmol}$ it did not produce nociception. Whereas, in combination with morphine, it attenuated morphine-induced antinociception and produced hyperalgesia in some rats. We hypothesize that activation of the NMDA-receptor by L-glutamic acid in the spinal cord results in attenuation of antinociception in rats. The NMDA, AMPA and EAA neurotransmitters have been shown to be involved in mediating spinal nociceptive neurotransmission resulting in intense pain. ${ }^{17}$ It is possible that endogenous EAA neurotransmitters released from nerve terminals in response to a noxious stimulus may be enhanced by it L-glutamic acid leading to attenuation of antinociception and hyperalgesia.

We have demonstrated the abolition of the attenuating effect of L-glutamic acid on morphine-induced antinociception in the rats pretreated with $50 \mathrm{mmol}$ ketamine it. Ketamine, a phencyclidine (PCP) like dissociative an- aesthetic, is an NMDA-receptor blocker which effectively blocks NMDA-elicited nociceptive responses in the spinal cord. Our result, that ketamine abolished the effect of L-glutamic acid allowing the antinociceptive effect of morphine to be expressed, is in agreement with the findings of others. 7,30

Willcockson et al. ${ }^{12}$ reported that phencyclidine inhibited the responses of spino-thalamic tract cells to iontophoretically applied glutamate to noxious stimuli. In a recent study, Aanonsen et al. ${ }^{13}$ have shown that NMDA increases neuronal responses to peripheral noxious thermal stimulation and iontophoretically applied PCP decreased the NMDA induced neuronal firing rate. Thus, the present study provides evidence that activation of the NMDA-receptor by L-glutamic acid in the spinal cord is responsible for the attenuation of morphine-induced antinociception.

In some studies, ${ }^{18-20}$ selective NMDA-receptor antagonists, 3-(2-carboxy piperazin-4-yl) propyl-1-phosphonic acid (CPP) and MK-801 have been shown to inhibit the response to noxious stimuli and produce antinociception after intrathecal administration.

To determine whether naloxone interacts with $\mathrm{L}$ glutamic acid, ketamine and morphine, rats were treated with $1 \mathrm{mg} \cdot \mathrm{kg}^{-1}$ naloxone $\mathrm{im}$. It is interesting to observe in our study that a combination of L-glutamic acid and morphine produced great antinociception in rats pretreated with naloxone. The precise mechanism involved in these interactions remains to be defined. However, it is suggested that naloxone, like ketamine, acts on a sigma opioid/phencyclidine receptor which is related to the NMDA-receptor channel ${ }^{26,27}$ and blocks the nociceptive reflex at spinal site. Naloxone has an affinity as an antagonist for the receptors responsible for morphine antinociception. It is possible that naloxone in glutamate- 
treated rats behaves as an agonist at another set of opioid receptors to produce antinociception independent of morphine's site of action. Further, morphine has affinity for mu and kappa receptor subtypes and kappa-selective opioid agonists may, in fact, antagonize antinociceptive effect of mu selective agonists. ${ }^{28,29}$ We further suggest that under the influence of L-glutamate, naloxone is able to protect endogenous kappa antagonism of mu-receptor activity and augments morphine-induced antinociception in rats. Verification of these hypotheses, however, requires more extensive study.

In conclusion, L-glutamic acid attenuates morphineinduced antinociception at the spinal site and previous administration of ketamine abolishes this effect. However, in naloxone and L-glutamic acid treated rats, morphineinduced antinociception is preserved and augmented. We suggest that the activation of NMDA-receptors with $\mathrm{L}$ glutamate is responsible in the modulation of opioidinduced antinociception in the spinal site in rats and suggest further work to elucidate the precise mechanisms involved.

\section{References}

1 Watkins $J C$, Evans $R H$. Excitatory amino acid transmitters. Ann Rev Pharmacol Toxicol 1981; 21: 165-204.

2 Collingridge $G L$, Lester RAJ. Excitatory amino acid receptors in the vertebrate central nervous system. Pharmacol Rev 1989; 40: 143-209.

3 Murphy DE, Snowhill EW, Williams $M$. Characterization of quisqualate recognition sites in rat brain tissue using DL- $\left[{ }^{3} \mathrm{H}\right]$ - $\alpha$-amino-3-hydroxy- 5 -methylisoxazole-4propionic acid (AMPA) and a filtration assay. Neurochem Res 1987; 12: 775-81.

4 Rothman SM, Olney JW. Glutamate and the pathophysiology of hypoxic-ischemic brain damage. Ann Neurol 1986; 19: 105-11.

5 Choi DW. Dextrorphan and dextromethorphan attenuate glutamate neurotoxicity. Brain Res 1987; 403: 333-6.

$6 \mathrm{Kim}$ JP, Goldberg MP, Choi DW. High concentration of naloxone attenuate $\mathrm{N}$-methyl-D-aspartate receptormediated neurotoxicity. Eur J Pharmacol 1987; 138: 133-6.

7 Aanonsen LM, Wilcox GL. Nociceptive action of excitatory amino acids in the mouse: effects of spinally administered opioids, phencyclidine and sigma agonists. J Pharmacol Exp Ther 1987; 243: 9-19.

8 Dickenson AH, Sullivan AF. Evidence for a role of the NMDA receptor in the frequency dependent potentiation of deep rat dorsal hom nociceptive neurons following $\mathrm{C}$ fibre stimulation. Neuropharmacology 1987; 26: 1235-8.

9 Yaksh TL. Behavioural and autonomic correlates the tactile evoked allodynia produced by spinal glycine inhibition: effects of modulatory receptor systems and excitatory amino acid antagonists. Pain 1989; 37: 111-23.
10 Haley JE, Sullivan AF, Dickenson $A H$. Evidence for spinal N-methyl-D-aspartate receptor involvement in prolonged chemical nociception in the rat. Brain Res 1990; 518: 218-26.

11 Woolf CJ, Thompson SW. The induction and maintenance of central sensitization is dependent on N-methyl-D-aspartic acid receptor activation: implications for the treatment of post-injury pain hypersensitivity states. Pain 1991; 44: 293-9.

12 Willcockson WS, Kim J, Shin HK, Chung JM, Willis $W D$. Actions of opioids on primate spinothalamic tract neurons. J Neurosci 1986; 6: 2509-20.

13 Aanonsen LM, Lei S, Wilcox GL. Excitatory amino acid receptors and nociceptive neurotransmission in rat spinal cord. Pain 1990; 41: 309-21.

14 Näsström J, Karlsson U, Post C. Antinociceptive actions of different classes of excitatory amino acid receptor antagonists in mice. Eur J Pharmacol 1992; 212: 21-9.

15 Kristensen JD, Post C, Gordh T Jr, Svensson BA. Spinal cord morphology and antinociception after chronic intrathecal administration of excitatory amino acid antagonists in the rat. Pain 1993; 54: 309-16.

16 Skilling SR, Smullin DH, Beitz AJ, Larson AA.

Extracellular amino acid concentrations in the dorsal spinal cord of freely moving rats following veratridine and nociceptive stimulation. J Neurochem 1988; 51: 127-32.

17 Headley PM, Parsons CG, West DC. The role of Nmethylaspartate receptors in mediating responses of rat and cat spinal neurones to defined sensory stimuli. J Physiol (Lond) 1987; 385: 169-88.

18 Eaton SA, Salt TE. N-methyl-D-aspartate antagonists reduce the responses of rat thalamic neurones to noxious stimulation. J Physiol (Lond) 1987; 394: 114 P.

19 Davar G, Hama A, Deykin A, Vos B, Maciewicz R. MK801 blocks the development of thermal hyperalgesia in a rat model of experimental painful neuropathy. Brain Res 1991; 553: 327-30.

20 Mao J, Price DD, Mayer DJ, Lu J, Hayes RL. Intrathecal MK-801 and local nerve anesthesia synergistically reduce nociceptive behaviors in rats with experimental peripheral mononeuropathy. Brain Res 1992; 576: 254-62.

21 Urca G, Nahin RL, Liebeskind JC. Glutamate-induced analgesia: blockade and potentiation by naloxone. Brain Res 1980; 192: 523-30.

22 van Praag $H$, Frenk $H$. The role of glutamate in opiate descending inhibition of nociceptive spinal reflexes. Brain Res 1990; 524: 101-5.

23 Jacquet $Y F$. The NMDA receptor; central role in pain inhibition in rat periaqueductal gray. Eur J Pharmacol 1988; 154: 271-6.

24 Yaksh TL, Rudy TA. Chronic catheterization of spinal subarachnoid space. Physiol Behav 1976; 17: 1031-6.

25 Davies $O L$, Raventós $J$, Walpole $A L$. A method for the 
evaluation of analgesic activity using rats. $\mathrm{Br} \mathbf{J}$ Pharmacol 1946; I: 255-8.

26 Mendelsohn LG, Kalra V, Johnson BG, Kerchner GA. Sigma opioid receptor: characterization and co-identity with the phencyclidine receptor. J Pharmacol Exp Ther 1985; 233: 597-602.

27 DeLander GE, Wahl JJ. In vivo characterization of phencyclidine/o agonist-mediated inhibition of nociception. Eur J Pharmacol 1989; 159: 149-56.

28 Janiri L, d'Amato $R$, Zieglgansberger $W$. Dynorphin 1-17 reduces the inhibitory actions of $\mathrm{mu}$ and delta-selective opioid agonists in cortical neurons of the rat in vivo. Neurosci Lett 1988; 84: 79-83.

29 Vaccarino $A L$, Tasker $R A R$, Melzack $R$. Analgesia produced by normal doses of opioid antagonists alone and in combination with morphine. Pain 1989; 36: 103-9.

30 Klepstad P, Maurset A, Moberg ER, Øye I. Evidence of a role for NMDA receptors in pain perception. Eur $J$ Pharmacol 1990; 187: 513-8. 